\title{
Raising the quality of designers' professional training through STEAM and CLIL
}

\author{
Ekaterina Sergeevna Marnitcyna ${ }^{1}$ and Ksenia Vladimirovna Kaisheva \\ Saint Petersburg State University of Industrial Technologies and Design, Foreign Languages \\ Department, Saint Petersburg, Russia
}

\begin{abstract}
The issues of quality assurance in the process of professional training have always been widely discussed. The current research presents the English for Academic Purposes section of the English language course design based on the STEAM approach and the feedback model for its evaluation. The study aims to assess the role of the English language course in building professional competencies with the help of the STEAM instructional design. Qualitative and quantitative methods, a formative pedagogical experiment, and an online survey were conducted. The study shows that interdisciplinary course evaluation can be based on feedback and outcomes indicators. The content and language integrated learning methods are perceived by the students as relevant. STEAM-based course design motivates students to perform fundraising activities for further professional development and continue improving their English language skills. Thus the English language can become a valid and stable base for further interdisciplinary projects in university education. The research found that the majority of the first-year art and design students learned about MOOCs for the first time and took courses to improve their professional skills during the English Language course. The authors conclude that STEAM and CLIL methodologies have much in common and are positively evaluated by both students and academics.
\end{abstract}

Keywords: educational quality, foreign language, STEAM, CLIL, art and design students

\section{Introduction}

Large-scale reforms implemented in the Russian educational system recently have become an integral part of the educational process and have already made some impact on the real studying and teaching practices. We have definitely come to the stage when we can discuss and analyze some of them.

The research focuses on the ways of improving the quality of education based on STEAM approach and highlights the role of the foreign language (the English language) as an auxiliary discipline when teaching art and design students. Even though the English language cannot be underestimated today and is acknowledged as lingua franca in scientific

${ }^{1}$ Corresponding author: ekaterinamarn@gmail.com 
and academic spheres [1] according to new trends in higher education in Russia, its role (i.e. contact hours) is diminishing. However the linguists are trying to do their best to improve the English syllabus and further develop and hone students' skills, thus the new recommended syllabus includes not only traditional modules like General English, Business English and English for Specific Purposes (for professional communication) but English for Academic purposes [2], which is part of the international trend and is marked and researched in many countries, for instance, need analysis show that English for academic purposes is one of students' priorities in other countries as well [3]. Some linguists even claim that teaching ESP (English for specific purposes) at university level will soon be divided into EAP (English for academic purposes) and EOP (English for occupational/professional purposes) [4], which have already happened in some higher educational establishments. New textbooks, teaching materials and research results have been published on the topic [5-7].

\section{$2 \quad$ Methods and materials}

The current experiment was designed to prove that the English language could become an integral part of university curriculum, could be widely used in interdisciplinary tasks and thus it can contribute to developing both soft and hard skills. The experiment was based on the modern STEAM approach which emphasizes promotion of creativity with rationalization, this is interdisciplinary approach which focuses on creativity and problem-solving skills [8-10].

The forming pedagogical experiment was conducted in 2017-2018 at Saint Petersburg State University of Industrial Technologies and Design. The Academic Mobility section (the name used in the university as an equivalent to the term English for Academic Purposes) of the English syllabus taught to undergraduate students of the university was supported by a special textbook and online course designed on the university MOODLE platform, both being developed by the academics of the foreign languages department of the above-mentioned university.

Key areas of exploration included the ability of students to learn and study, new opportunities for acquiring professional skills, chances to study the chosen profession (design) abroad or online. The aim was to encourage students to study and develop individually not only within the English language curriculum but professionally and personally as well and to share the skills within and across art and design (their major) and auxiliary disciplines (such as a foreign language).

The experiment consisted of three phases. In the first stage, the content analysis of the best STEAM practices and methods was done, and the syllabus was designed. In the second stage, the course General English together with Academic Mobility section was delivered to the first-year students majoring in art and design. Face-to-face classes took place twice a month (totally 17 contact hours) and each face-to-face class was supported by online session which included the lesson plan (covering both the contact hours for students who missed the class to be able to catch up and online activities description). Online activities included exercises to revise new vocabulary, a text with pre- and post-reading activities and minimum one extra activity such as working out personal development plan, writing a CV, recording a video with self-presentation, writing an essay, etc. All tasks had a deadline to encourage students to build self-discipline. The final assessment was organized as a board game and group presentations (for oral practice) and as a final written test. In the third stage, the learning outcomes were assessed and the feedback using an online survey was 
gathered. Qualitative and quantitative research methods were employed to interpret the survey results.

Students' feedback is acknowledged to be an effective tool to correct and improve the educational process and is prescribed to be used in all countries implementing the Bologna process [11]. Feedback is a foundation to provide any process with quality assurance and basing on it, it is possible to find a reasonable balance between teachers' control and students' independent work.

Moreover, the desktop analysis of scientific literature, i.e. publications in peer-reviewed scientific journals cited in Web of Science research intelligence platform was conducted. The analysis of papers published in 2015-2020 showed rapid growth in the number of publications proposing tools and strategies of raising the quality of professional training based on STEAM approaches [12, 13]. Being a widely discussed in scientific discourse phenomena, education quality has a great variety of valid methods. The current research uses UNESCO's conceptualization of quality: a framework for understanding, monitoring and improving education quality [14]. UNESCO's methodology for quality assessment has been applied for more than 50 years and matches the requirements of interdisciplinary research. UNESCO proposes 4 dimensions that influence the core processes of teaching and learning: contextual; enabling inputs; teaching and learning; outcomes. STEAM practices on a course level can be measured with the help of the last two dimensions. The outcomes and feedback indicators for evaluating the quality of the designer's professional training were used to assess the effectiveness of STEAM-CLIL approaches embedded into the Academic Mobility section of the English syllabus.

The survey was conducted with the assistance of the university Quality Assurance Department which is in line with the University policy and meets the demands of Bologna process. The survey was published on the University's official website and consisted of 22 questions to cover different aspects of the English for academic purposes course, e.g. online support, opinion on new types of activities, etc., and included Likert scale question types and open-ended questions. 93 students participated in the experiment. 87 survey responses were gathered. The survey aimed at collecting students' feedback and investigating opinion of the participants on the new part of the English syllabus and if it contributed to both their personal and professional development. This article considers six questions logically connected with the aim of the research and with each other.

\section{$3 \quad$ Results}

Taking into consideration that traditional and STEAM-based English courses have the same learning outcomes it is reasonable to analyze the feedback parameters to evaluate the quality. The results are presented in two diagrams in accordance with the question type and the method. 


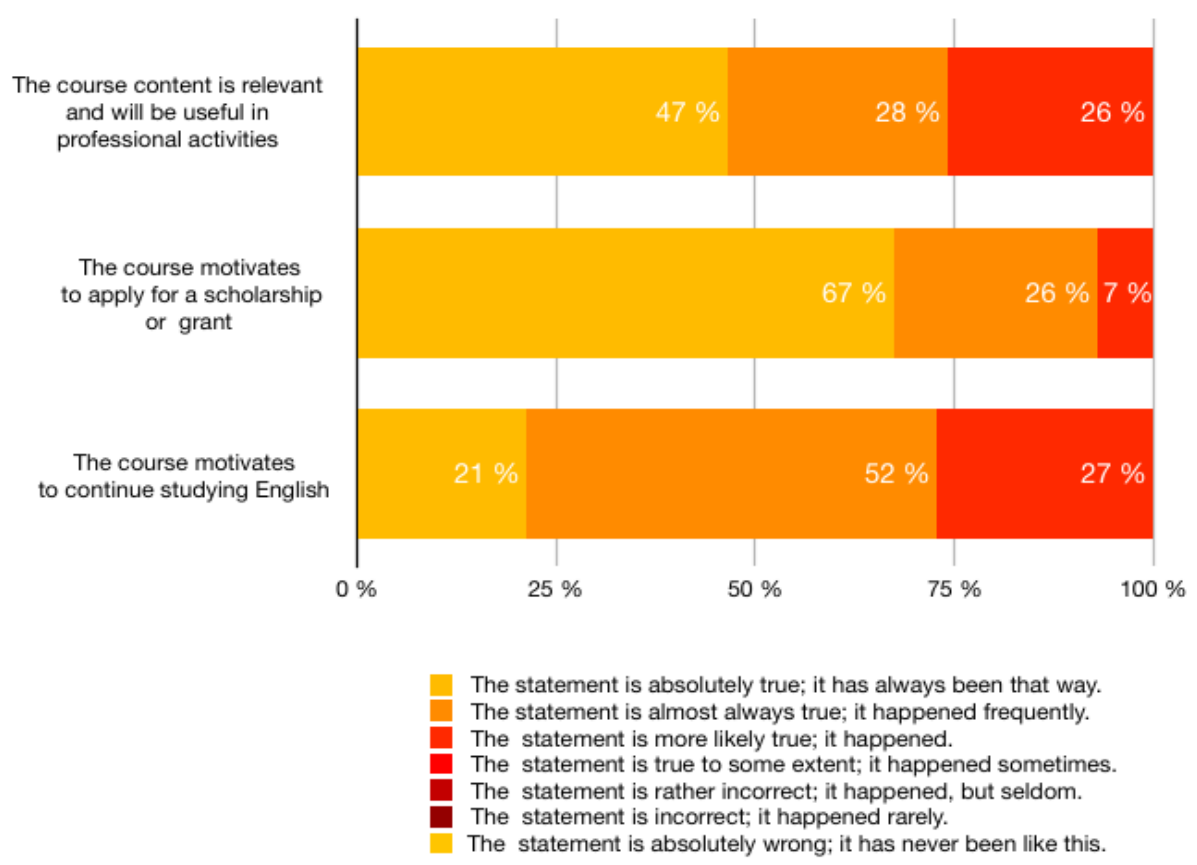

Fig. 1. Diagram 1.

Being an interdisciplinary approach STEAM focuses on problem-solving activities and innovations. Survey results presented in diagram 1 show that this project-based teaching and learning strategy motivates students to apply for a scholarship or any other funding source. More than half of respondents started considering the funding opportunities for their project. The traditional instructional design of English courses does not motivate students to perform fundraising activities.

Despite (or rather to say thanks to) the interdisciplinary character of the course it motivates respondents to continue studying the English language. 


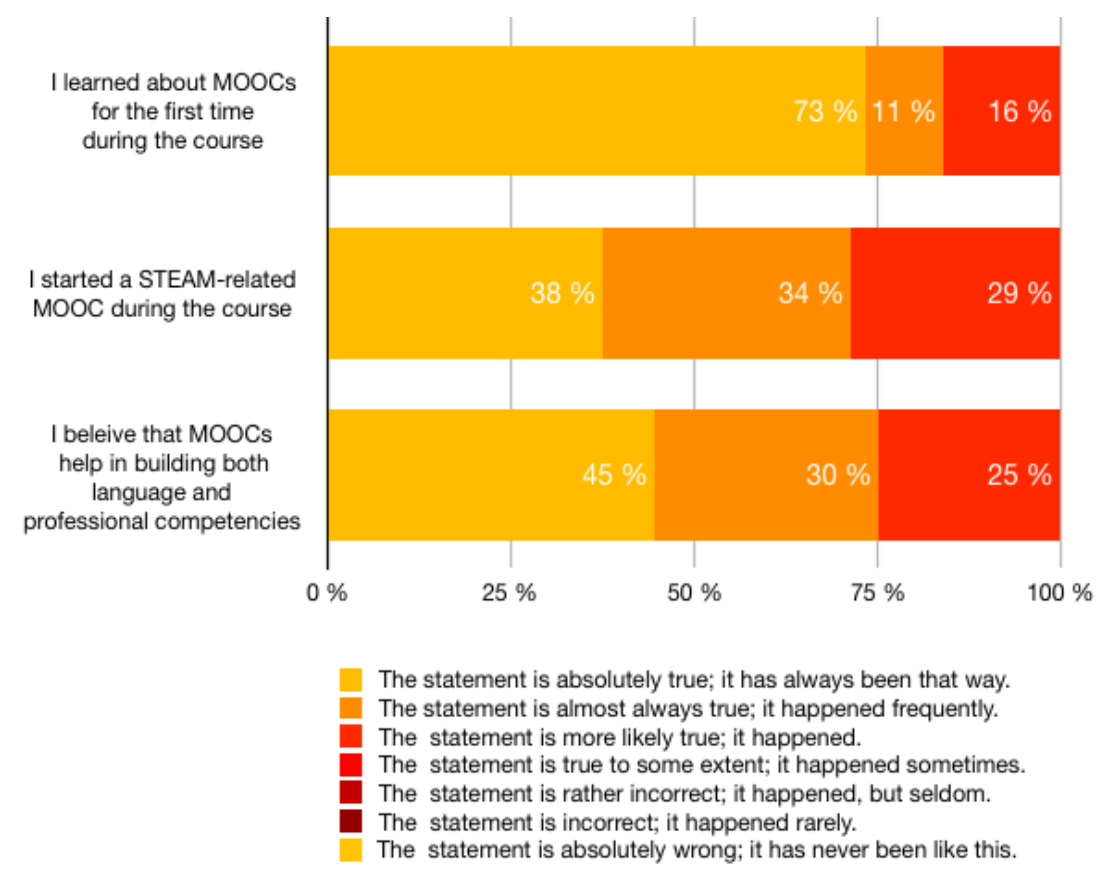

Fig. 2. Diagram 2.

The STEAM-based approach requires wide interdisciplinary knowledge. It is almost impossible to achieve the required level of STEAM subjects within a regular English course. To solve this problem, students were encouraged to choose and take any MOOC connected with their professional field or any other field where they lack skills. Surprisingly, as we see from Diagram 2, the majority of the first-year students never heard about MOOCs and the educational opportunities they provide. As a result, most of the students chose the course and started at least one of the MOOCs. Students found MOOC's to be an effective tool in studying both English and STEAM-subject or profession.

\section{Discussion}

The outcomes of the specially designed short course are very optimistic, you can see that students used only the three most positive answers of the Likert scale, which shows not only high level of students' satisfaction but good perspectives for further integrating the English language into university curriculum even at undergraduate level. Attempts to involve students into more profound independent work in their professional spheres turned out to be very successful by means of the foreign language; it is confirmed by the amount of students who agree that this course is useful for their occupation and by those, who really started a MOOC course. Three questions about MOOC do prove that English teachers managed to increase students' awareness of learning opportunities to develop any type of skill including professional skills. This brings us to new conclusions. Doing any course in the frame of MOOC in English (if it is not a mother tongue for a student) as a part of English for Academic Purposes with the assistance of an English teacher the process becomes a real content and language integrated learning (CLIL) practice. The STEAM methodology has much in common with CLIL and deals with building up both language 
and professional competencies and skills. CLIL is defined by its founder D. Marsh as a dual-focused educational approach when a foreign language is used for learning and teaching a new subject and the language itself with the aim to master both (the language and the subject) $[15,16]$. Developing the ideas of D. Marsh linguists teaching languages and applying to CLIL methods concluded that the content here is the base [17]. This is exactly what happened when we forwarded students to MOOC in the frame of the English course, students concentrated on the content using the English language as a tool but still learning it. To go further we can involve a teaching strategy called 'collaborative teaching', when two teachers, a language teacher and a content teacher, cooperate [18], even though this type of cooperation is more reasonable at a later stage.

\section{Conclusion}

Even though this connection was confirmed by the experiment, attempts to marry these two approaches are already studied, encouraged and funded, for example, projects developed in the frame of the European project CLIL for STEAM funded by the Erasmus+ Programme of the European Union. Moreover, current interest in STEM/STEAM education generates a lot of interesting research, real practice description, their analysis and systematization [19] which could be applied to education process at different levels. This approach is perceived by both students and educator as relevant and it should not be missed by curriculum, syllabus and module template designers at university level to further develop professional skills and to save some auxiliary disciplined in the educational process.

\section{References}

1. A. Mauranen, Helsinki Eng Stud, 6(6), 28 (2010)

2. S.G. Ter-Minasova, E.N. Solovova, Inostrannyi yazyk dlya neyazykovykh vuzov i fakul'tetov, primernaya programma [Foreign language for non-linguistic universities and faculties, sample program] (Moscow, 2009)

3. T.A. Parnawati, A. Ulinuha, Premise J, 8(2), 226-240 (2019). https://doi.org/10.24127/pj.v8i2.2296

4. A. Kusni, Reformulating English for Specific Purposes (ESP) in Indonesia: Current issues and future prospects, in Proceedings of National Seminar on English Language Teaching, 36-48 (Universitas Negeri Padang, Padang 2013)

5. S.V. Bogolepova, Bul Omsk State Pedag Univ. Human Stud, 1(2), 36-39 (2014)

6. I.B. Korotkina, Domestic Foreign Pedagogy, 4(52) (2018)

7. E.V. Dvoretskaya, Questions Mod Sci Prac, 1, 147-152 (2016). https://doi.org/10.17277/voprosy.201601.pp.147-152

8. A. Harris, L.R. de Bruin, Aust. Art Educ, 38, 54-75 (2017)

9. J.C. Hong, C.H. Chang, C.R. Tsai, K.H. Tai, Int. J. Sci. Edu, 41, 1667-1681 (2019). https://doi.org/10.1080/09500693.2019.1624992

10. C. Lin, J. Huang, R. Lin, Edu Sci, 11, 171 (2021).

https://doi.org/10.3390/educsci11040171

11. J. Kettunen, M. Kantola, Edu Manag, 12:3, 257-267 (2006).

https://doi.org/10.1080/13583883.2006.9967172 
12. D. Herro, et al., Int J STEM Edu, 4(1), 1-12 (2017). https://doi.org/10.1186/s40594-017-0094-z

13. N.H. Kang, Asia Pac. Sci. Edu, 5, 6 (2019). https://doi.org/10.1186/s41029-019-0034-y

14. A New generation of external quality assurance dynamics of change and innovative approaches. International Institute for Educational Planning (2021). Accessed on: September 24, 2021. [Online]. Available: https://unesdoc.unesco.org/ark:/48223/pf0000377497?posInSet=1\&queryId=dbddbb76 -396c-4e27-a915-aadc20cbe41d

15. D. Marsh, P. Mehisto, D.Wolff, M. Frigols-Martin The European Framework for CLIL Teacher Education (European Centre for Modern Languages (ECML), Graz, 2010)

16. D. Marsh, Content and Language Integrated Learning (CLIL). A Development Trajectory (University of Cordoba, 2012)

17. L.P. Khalyapina, Bul PNRPU. Prob Ling Pedag, 2, 149-155 (2017)

18. D. Poedjiastutie, Edu Res Rev, 12(6), 338-349 (2017). https://doi.org/10.5897/ERR2016.3125

19. C. Liao, Creating a STEAM Map: A Content Analysis of Visual Art Practices in STEAM Education, in Khine M., Areepattamannil S. (eds) (STEAM Education. Springer, Cham 2019). https://doi.org/10.1007/978-3-030-04003-1_3 